\title{
OPIS ŚWIĄTYNI MĄDROŚCI BOŻEJ W KONSTANTYNOPOLU PROKOPIUSZA Z CEZAREI - MIĘDZY HISTORIOGRAFIĄ A RETORYKĄ
}

Opis świątyni Mądrości Bożej w Konstantynopolu zawarty przez Prokopiusza z Cezarei w dziele pt. O budowlach to cenne źródło do poznania dziejów budowy głównego kościoła w stolicy Cesarstwa Bizantyńskiego. Mając na uwadze zastrzeżenia Henry'ego Maguire'a: The Byzantine ekphraseis copied ancient models not only in their general standard of judgment, but also in their specific language. There was a constant repetition of clichés, paraphrases, and quotations, some of which were of considerable length. These topoi cast further doubt on the accuracy of the ekphraseis ${ }^{\mathrm{T}} \mathrm{w}$ odniesieniu do ekfrazy Prokopiusza warto za nim zapytać: how often Byzantine writers looked at the works which they described, and how far their descriptions were purely literary exercises, based on written models?2. Jest to tym bardziej zasadne, gdy zauważymy, że kościół Mądrości Bożej zachował się do naszych czasów, a zmiany, jakim przez wieki podlegał, zasadniczo nie zmieniły koncepcji z czasów Justyniana I. w znaczący sposób Prokopiusz zaś musiał oglądać świątynię na własne oczy. Można zatem porównać tekst $\mathrm{z}$ istniejącą budowlą.

\section{Prokopiusz z Cezarei i jego dzieło $\boldsymbol{O}$ budowlach}

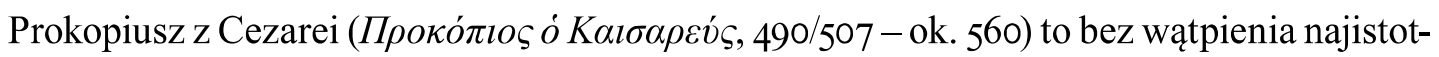
niejszy historiograf epoki wczesnobizantyńskiej. Badacze zwykle uznają, iż jego rodzinnym miastem była Cezarea w Palestynie Pierwszej (Palestina Prima) ${ }^{4}$. Prokopiusz związał się z dworem cesarza Justyniana I (527-565), który w 527 r. mianował go osobistym sekretarzem

\footnotetext{
H. Maguire, Truth and Convention in Byzantine Descriptions of Works of Art, „Dumbarton Oaks Papers”, 28/1974, s. 114.

2 Ibidem.

3 Dobry wgląd w najnowsze ustalenia dotyczące historiografa daje: G. Greatrex, Perceptions of Procopius in Recent Scholarship, „Histos”, 8/2014, s. 71-121.

$4 \quad \mathrm{Na}$ początku swej Historii wojen przedstawił się w następujący sposób (Bell. 1.1.1.): Prokopiusz z Cezarei opisat wojny, które Justynian, cesarz Rzymian, prowadzit z barbarzyńcami ze Wschodu i Zachodu, zgodnie z tym,

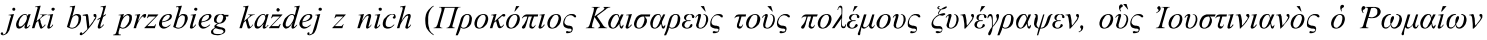

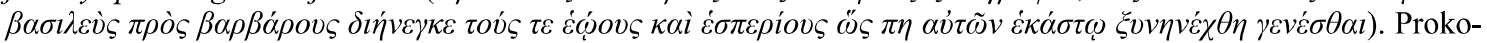
piusz z Cezarei, Historia wojen, t. 1: Wojny z Persami i Wandalami, z języka greckiego przeł., wstępem poprzedził, komentarzem opatrz. D. Brodka, Kraków 2013, 1.1.1., s. 5; Procopius, De bellis libri 1-4, w: Procopii Caesarensis opera omnia, red. J. Haury, add. et corr. G. Wirth, Leipzig 1962, t. 1 (4), 1.1.1.
} 
i doradcą prawnym Belizariusza (ok. 505-565), naczelnego wodza bizantyńskiej armii5. Z nim też uczestniczył w wielu wyprawach wojennych. Kontakty Prokopiusza z Belizariuszem zostały ograniczone, gdy wódz w 542 r. popadł w niełaskę. Po tej dacie niejasne stają się także dalsze losy Prokopiusza, być może wówczas osiadł on na stałe w Konstantynopolú.

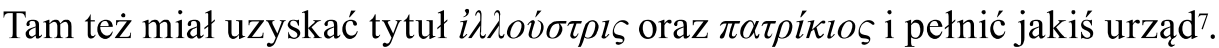

Po odejściu z armii resztę swego życia poświęcił na działalność literacką. Znamy jego

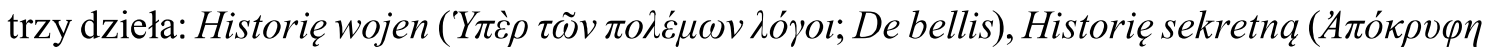

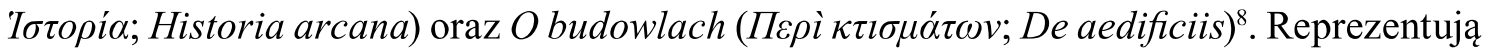
one trzy różne gatunki: historię wojenną, pamflet i panegiryk. Chronologia powstawania poszczególnych tekstów jest wciąż przedmiotem sporów badawczych ${ }^{9}$. Przyjmuje się jednak, iż w połowie lat czterdziestych Prokopiusz już pracował nad Historia wojen, a w 55I r. była gotowa edycja ksiąg I-VII (VIII około 554 r.). Z podobnego okresu może pochodzić także Historia sekretna. O budowlach zaś, jako dzieło najpóźniejsze, datuje się zwykle albo na

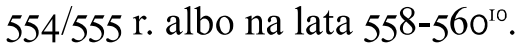

W Historii wojen Prokopiusz opisał zmagania z Persami, Wandalami oraz z Gotami, a także zawarł przegląd wydarzeń do 554 r. Z kolei Historia sekretna, pomyślana jako swoiste uzupełnienie do dzieła o wojnach, to ostra krytyka cesarza Justyniana I i cesarzowej Teodory oraz Belizariusza i jego żony Antoniny. W O budowlach autor wychwala Justyniana jako fundatora ogromnej ilości budynków.

Uznanie działalności budowlanej za powód do chwały, co zauważył Piotr Ł. Grotowski, wpisuje się w przemiany panegiryku, które nastąpiły na początku IV w. Wówczas bowiem w mowach pochwalnych zaczęto uwzględniać także cesarskie dokonania na polu architektury, w których widziano dbałość o dobro państwa. Wzorcowym przykładem takiego podejścia

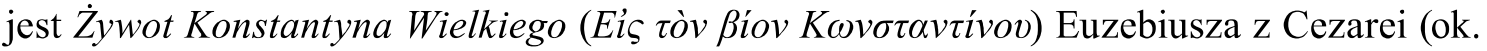
260/265-339). Autor omówił tam zarówno główne osiągnięcia polityczne i wojskowe, jak i fundacje architektoniczne. Dzieło Prokopiusza więc nie odbiega w swej tematyce od standardów epoki i stanowi dobry przykład późnoantycznego panegiryku ${ }^{\text {II }}$. Wydaje się, iż poprzez napisanie tej pochwały autor chciał zyskać cesarską przychylność lub za coś podziękować, a ponieważ przyjęta konwencja literacka nie wymusza szczerości, to jego negatywny stosunek do Justyniana mógł pozostać niezmienny ${ }^{12}$. Z drugiej strony, na co wskazuje

O. Jurewicz, Historia literatury bizantyńskiej, Wrocław-Warszawa-Kraków 2007, s. 32-33.

D. Brodka, Wstęp, w: Prokopiusz z Cezarei, Historia wojen, t. 1, s. XX-XXI.

P.Ł. Grotowski, Pochlebca czy oszczerca? Janusowe oblicze Prokopiusza, w: Prokopiusz z Cezarei, O budowlach, przeł., wstępem, objaśnieniami i komentarzami opatrz. P.Ł. Grotowski, Warszawa 2006, „Biblioteka Antyczna", s. 50.

8 W. Siwakowska, Prokopios, w: Stownik pisarzy antycznych, red. A. Świderkówna, Warszawa 1982, s. 390-391.

9 Streszczenie poglądów dotyczących datowania poszczególnych dzieł Prokopiusza, cf. D. Brodka, op. cit., s. XXII. Zob. także: P.Ł. Grotowski, op. cit., s. 51, 62-64.

10 D. Brodka, op. cit., s. XXII. Zob także: G. Greatrex, op. cit., s. 101-103.

11 P.ł. Grotowski, op. cit., s. 57-60. Dzieło Prokopiusza jednak wprowadza też nową jakość, ponieważ pochwała budowlanych dokonań to osobne, obszerne dzieło, a nie jedynie element innego tekstu. Cf. J. Elsner, The Rhetoric of Buildings in the "De Aedificiis" of Procopius, w: Art and Text in Byzantine Culture, red. L. James, Cambridge 2007, s. 35.

12 D. Brodka, op. cit., s. XXVII-XXVIII. Warto zauważyć, iż Prokopiusz w swych dziełach, w tym w O budowlach, nierzadko posługuje się subtelną ironią. Tak że wiele informacji ma niejednoznaczny wydźwięk. Autor na tyle dobrze opanował warsztat pisarski, że potrafił wpleść - nawet w tekst mający być jedną wielką pochwałą - gorzkie 
Oktawiusz Jurewicz, O budowlach mogło stanowić retoryczny popis w formie literackiej

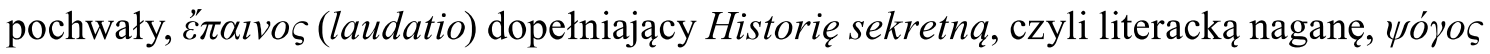
(reprehensio, vituperatio) ${ }^{\mathrm{r}}$. Wiadomo bowiem, że pisanie zarówno pochwał, jak i nagan na temat tej samej osoby było jednym z podstawowych ćwiczeń retorycznej edukacji ${ }^{14}$. Pewna innowacyjność autora polega przede wszystkim na podejściu do zebranych danych. Można bowiem zauważyć, iż Prokopiusz wykazuje stosunkowo niewielkie zainteresowanie kwestiami estetycznymi, a nawet - poza księgą pierwszą - wyglądem opisywanych budowli, dając raczej katalogi budynków z poszczególnych terenów, co może świadczyć o wpływie kronik z VI w. zawierających wykazy budowli' ${ }^{15}$.

Dzieło $O$ budowlach zostało podzielone na sześć rozdziałów, którym przypisano poszczególne obszary geograficzne: Konstantynopol (ks. I), Syria (ks. II), Armenia (ks. III), prowincje bałkańskie (ks. IV), Azja Mniejsza i Palestyna (ks. V) oraz Afryka (ks. VI). Prokopiusz opisuje w nich budowle kościelne (kościoły i klasztory), militarne (fortyfikacje, twierdze) oraz hydrotechniczne (porty, mosty, kanały, zapory). Analiza ksiąg wykazuje, iż są one w różnym stopniu dopracowane i dokładne. Najlepsze wrażenie sprawia część dotycząca Konstantynopola, w której narracja jest spójna i zawiera wiele nawiązań do dzieł dawniejszych autorów. Na tym tle szczególnie blado ukazują się księgi IV i V, napisane chaotycznie, a niekiedy sprowadzające się jedynie do nieuporządkowanej listy miejscowości. Tego typu spostrzeżenia skłoniły badaczy do uznania, iż dzieło pozostało nieukończone. Przerwanie pracy mogło być spowodowane śmiercią autora, który zdołał nadać ostateczny kształt jedynie początkowym częściom, pozostałe zaś pozostawił częściowo $\mathrm{w}$ formie nieogładzonych notatek. Kolejnym argumentem przemawiającym na rzecz tej tezy jest brak wzmianek o fundacjach w Italii, którą Justynian na powrót włączył w granice Cesarstwa ${ }^{16}$. Jest więc wielce prawdopodobne, iż zachowane do naszych czasów dzieło jedynie w pewnym stopniu ukazuje zamysł swego autora.

Można jednak także rozważyć, czy słabszy styl oraz brak precyzyjniejszych danych w niektórych rozdziałach nie jest wynikiem braku dostatecznych informacji o danym regionie. Wiadomo bowiem, że wiele z dobrze opracowanych miejsc to rejony, w których autor przebywał osobiście w trakcie kampanii wojennych. Miał więc możliwość autopsji oraz czerpania z miejscowych źródeł, a także poznania rozmaitych anegdot, które lubi włączać w swą opowieść, aby ją ożywić i uczynić ciekawszą. Wyraźne dysproporcje stylu zauważalne są również w opisach różnych rodzajów obiektów - dość dokładne są te, które dotyczą infrastruktury militarnej. Prokopiusz pisze je z pewnym zrozumieniem ich funkcji oraz mechanizmów działania, nie szczędzi przy tym fachowego słownictwa. Opisy innej architektury nie są już tak jasne, nierzadko miewa w nich trudności z precyzyjnym omówieniem niektórych elementów konstrukcyjnych i raczej ogranicza się do archaizującego języka, unikając współczesnej mu terminologii z zakresu architektury, która została już wzbogacona o osobne określenia na elementy architektoniczne specyficzne dla budowli bizantyńskich.

aluzje, które zapewne bardziej odpowiadały jego osobistym przekonaniom, ale zarazem nie przesłaniały podstawowej wymowy utworu. Cf. także: P.Ł. Grotowski, op. cit., s. 69-70.

13 O. Jurewicz, op. cit., s. 39.

14 Na temat różnorodności gatunkowej zastosowanej przez Prokopiusza w O budowlach, zob.: J. Elsner, op. cit., s. 35-39.

15 Av. Cameron, Procopius and the Sixth Century, London-New York 1996, s. 90.

16 Cf. P.Ł. Grotowski, op. cit., s. 53-57, 60-62. 
Obecnie wskazuje się również, iż Prokopiusz nie uniknął błędów w swych opisach oraz że pisał jako laik (choć pozujący na znawcę tematu) dla odbiorcy, który nie posiadał dobrej orientacji w kwestiach technicznych ${ }^{17}$. Być może więc problem niejednorodności stylistycznej O budowlach to wypadkowa większej liczby czynników, niż tylko śmierci autora, który nie zdążył swego dzieła dopracować?

\section{Kościół Mądrości Bożej w Konstantynopolu}

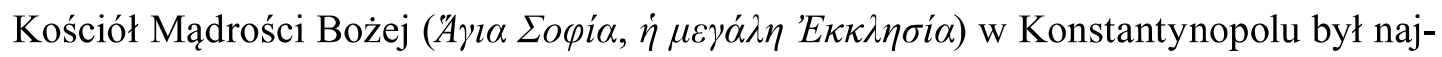
ważniejszą świątynią w Cesarstwie Bizantyńskim. Budowę pierwszego kościoła rozpoczął cesarz Konstantyn I Wielki (306-337) lub jego syn Konstancjusz II (337-36I) ${ }^{18}$. Konsekracji dokonano w 360 r. Kościół w swej pierwotnej formie był stropową bazyliką - charakterystyczną dla świątyń wczesnochrześcijańskich ${ }^{19}$. W 404 r. został zniszczony przez pożar i następnie odbudowany. Kres tej fundacji przyniosło powstanie Nika w styczniu 532 r., kiedy to I3 stycznia budynek doszczętnie spłoną $1^{20}$. Justynian, po stłumieniu powstania, zdecydował o zbudowaniu nowej świątyni - w innej formie i przekraczającej dotychczasowe kościoły wielkością i bogactwem dekoracji ${ }^{21}$.

Budowa została powierzona Antemiuszowi z Tralles i Izydorowi Starszemu z Miletu. Prace trwały od roku 532 do 27 grudnia 537 r., kiedy świątynię uroczyście konsekrowano. Kościół jest założeniem centralno-kopułowym z elementami planu bazylikowego, wzniesionym z cegły i kamienia (w partiach nośnych). Główną przestrzeń wyznaczono przez cztery potężne filary, na nich wspierają się arkady oraz pendentywy, które pozwalają na przejście do formy kolistej, wieńczonej przez ogromną kopułę. Jest ona od strony wschodniej i zachodniej wsparta przez cztery niższe półkopuły z eksedrami. Nawy boczne wydzielono za pomocą kolumnowych arkad, nad których wsparto empory. Od zachodu zaś znajduje się prostokątny narteks (podwójny, wewnętrzny i zewnętrzny), do niego też przylegało atrium otoczone $\mathrm{z}$ trzech stron kolumnowym portykiem ${ }^{22}$.

Wzniesienie tak śmiałej budowli było poważnym wyzwaniem konstrukcyjnym, przy którym niektórych problemów nie udało się rozwiązać za pierwszym razem. Tak było z pierwotną kopułą, która częściowo runęła w 558 r., osłabiona trzęsieniami ziemi z lat 553 i 557 . Odbudował ją w 563 r. Izydor Młodszy (siostrzeniec lub syn Izydora Starszego), zastosowując kilka zmian, które miały wzmocnić konstrukcję: podwyższył ją o 7 metrów,

17 Cf. G. Greatrex, op. cit., s. 104.

18 R. Krautheimer, The Constantinian Basilica, „Dumbarton Oaks Papers”, 21/1967, s. 133-138.

19 Na temat formy kościoła Mądrości Bożej w Konstantynopolu sprzed przebudowy Justyniana, v. R.J. Mainstone, Hagia Sophia: Architecture, Structure and Liturgy of Justinian's Great Church, London 1988, s. 128-143.

20 A. Różycka Bryzek, Hagia Sophia, w: Encyklopedia kultury bizantyńskiej, red. O. Jurewicz, Warszawa 2002, s. 193; S. Bralewski, Konstantynopolitańskie kościoły, w: Konstantynopol Nowy Rzym. Miasto i ludzie w okresie wczesnobizantyńskim, red. M.J. Leszka, T. Wolińska, Warszawa 2011, s. 145-147.

21 Prokopiusz jest zdania, że sam Bóg zezwolił na niegodziwy czyn powstańców, żeby Justynian mógł wznieść nowy, wspanialszy kościół (Aed. 1.1.21): A Bóg pozwolił im na to świętokradztwo, bo przewidziat, jak pięknie owa

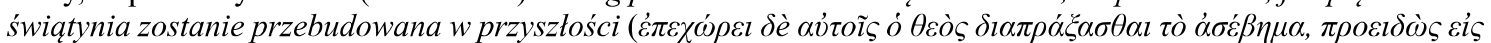

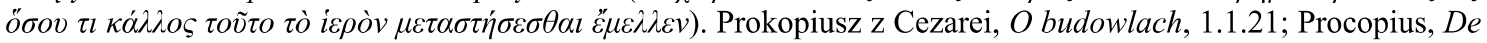
aedificiis, w: Procopii Caesarensis opera omnia, red. J. Haury, add. et corr. G. Wirth, Leipzig 1964, t. 4 (4), 1.1.21.

22 Szczegóły na temat konstrukcji i formy architektonicznej kościoła Mądrości Bożej fundacji Justyniana, zob.: R.J. Mainstone, op. cit., s. 184-217. 
wzniósł przypory, które sięgają podstawy kopuły, a także gurty do wysokości gzymsu ${ }^{23}$. W późniejszym okresie również dochodziło do pewnych uszkodzeń kościoła, m.in. w roku 989 i i346. Obecny wygląd świątyni - także jej wnętrza - jest również wynikiem ingerencji tureckich, dokonywanych po I453 $\mathrm{r}^{24}$

$\mathrm{Na}$ pierwotne wyposażenie wnętrza świątyni składały się: synthronon, ołtarz z cyborium, marmurowy templon oraz solea prowadząca od świętych drzwi templonu do ambony, znajdującej się pod kopułą, a także loża cesarska przy południowo-wschodnim filarze ${ }^{25}$. Niezwykłe było także bogactwo materiałów zastosowane do dekoracji. By tylko wskazać: różnobarwne marmury sprowadzone $\mathrm{z}$ różnych zakątków świata ${ }^{26}$, które posłużyły do wykonania okładziny oraz kolumn, a także mozaiki o motywach ornamentalnych i figuralnych lub całkowicie złote, pokrywające wszystkie powierzchnie powyżej gzymsu²7.

\section{Opis kościoła Mądrości Bożej w Konstantynopolu Prokopiusza z Cezarei (Aed. 1.1.20-78)}

Prokopiusz opisał pierwszą wersję (532 r.) kościoła Mądrości Bożej fundacji Justyniana I, choć w jego tekście znajduje się pewna wzmianka, którą niektórzy badacze interpretują jako aluzję do zawalenia się kopuły w $55^{8} \mathrm{roku}^{28}$ : Wydaje się, jakby wisiat [chodzi o wschodnią konchę podtrzymującą kopułę - MG] w powietrzu bez pewnego oparcia podstawy, a wznoszac się tak wysoko - zagrażał zawaleniem na tych, którzy znajduja się w pobliżu ${ }^{29}$. Autor jednak nigdzie nie wypowiedział się wprost o późniejszej katastrofie.

Opis jest obszerny, zajmuje bowiem ponad połowę pierwszego rozdziału księgi pierwszej (Aed. I.I.20-78). Kościół Mądrości Bożej w Konstantynopolu został omówiony przez Prokopiusza jako pierwszy, co wyraźnie podkreśla najwyższą rangę tej świątyni w całym Cesarstwie. Autor pozwolił sobie także na krótkie dygresje dotyczące okoliczności budowy oraz inżynierów za nią odpowiedzialnych, a także wkładu cesarza, który pomógł rozwiązać niektóre z problemów konstrukcyjnych. Dygresje znajdują się na początku i końcu opisu, stanowiąc swego rodzaju klamrę spinającą, która uwypukla znaczenie cesarza w całym przedsięwzięciu - najpierw zainicjował budowę, następnie zaś pomógł w jej szczęśliwym zakończeniu. Został więc zaprezentowany jako przykładny fundator, który troskliwie czuwa nad budową.

23 V. K.J. Conant, The First Dome of St. Sophia and Its Rebuilding, „American Journal of Archaeology”, 43/1939, nr 4, s. 589-591; R.J. Mainstone, Justinian's Church of St Sophia, Istanbul: Recent Studies of Its Construction and First Partial Reconstruction, ,Architectural History”, 12/1969, s. 39-49 i 102-107; R. Taylor, A Literary and Structural Analysis of the First Dome on Justinian's Hagia Sophia, Constantinople, „Journal of the Society of Architectural Historians", 55/1996, nr 1, s. 66-78.

24 R. Krautheimer, Early Christian and Byzantine Architecture, New Haven-London 1986, s. 206 (revised by S. Ćurčić).

25 A. Różycka Bryzek, op. cit., s. 194.

26 V. N. Schibille, Hagia Sophia and the Byzantine Aesthetic Experience, Farnham 2014, s. 241-243.

27 R. Krautheimer, Early Christian and Byzantine..., s. 205-206; A. Różycka Bryzek, op. cit., s. 194.

28 V. Prokopiusz z Cezarei, O budowlach, 1.1.31, przyp. 24, s. 85.

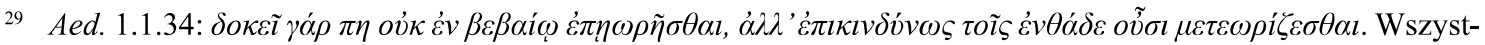
kie tłumaczenia cytatów na język polski za: Prokopiusz z Cezarei, O budowlach, przeł., wstępem, objaśnieniami i komentarzami opatrz. P.Ł. Grotowski, Warszawa 2006, „Biblioteka Antyczna”. 
Po pierwszej dygresji (Aed. I.I.20-26) następuje zwięzłe osadzenie świątyni w przestrzeni miasta oraz pochwała niezwykłej urody budowli (Aed. I.I.27), po czym autor wchodzi do wnętrza i podaje kilka ogólnych informacji, które wprowadzają w niezwykły klimat świątyni (Aed. I.I.28-30). Po tym wstępie Prokopiusz przystępuje do właściwego, szczegółowego opisu, który rozpoczyna od strony wschodniej, mieszczącej sanktuarium (Aed. I.I.3I-34) - a więc z poszanowaniem zasady hierarchii wnętrza. Następnie posuwa się ku stronie zachodniej, w której znajduje się narteks i wejścia (Aed. I.I.35-36), a potem wraca, by sporo uwagi poświęcić części centralnej, przekrytej ogromną kopułą (Aed. I.I.37-49). Stara się też wyjaśnić, w jaki sposób zapewniono konstrukcji stabilność, dając krótki wykład o głównych filarach (Aed. I.I.50-54). Po omówieniu najważniejszych struktur kieruje się ku nawom bocznym oraz emporom, zwracając przy tym uwagę na walory estetyczne wielobarwnej i błyszczącej dekoracji (Aed. I.I.54-63). W podsumowaniu Prokopiusz wspomina również o kosztownych darowiznach Justyniana (Aed. I.I.64-65), dzięki którym cesarz jawi się jako niezwykle hojny ofiarodawca, mający na uwadze również odpowiednią oprawę kultu. Po bardzo zwięzłym podsumowaniu (Aed. I.I.66-67), autor pozwala sobie na ostatnią dygresję, która wiąże się z trudnościami technicznymi, z jakimi Antemiusz z Tralles i Izydor Starszy musieli się borykać na placu budowy (Aed. I.I.68-78).

Opis kościoła Mądrości Bożej jest więc w swej strukturze przemyślany, kolejność omawianych partii jest logiczna: od usytuowania w krajobrazie miasta i widoku zewnętrznego ${ }^{30}$, do wnętrza, z zachowaniem hierarchii ważności poszczególnych części, a także z osobnym wyjaśnieniem najistotniejszych problemów konstrukcyjnych. Można więc stwierdzić, iż ustęp dotyczący głównej świątyni Konstantynopola został przez Prokopiusza skomponowany w dość przejrzysty sposób, nawet jeśli niekiedy autor nie do końca jest w stanie klarownie omówić niektóre elementy architektoniczne, co zapewne wynika z niewystarczającej wiedzy fachowej.

Pod względem gatunkowym tekst dotyczący świątyni Mądrości Bożej stanowi prozatorską formę ekfrazy ${ }^{31}(\varepsilon \kappa \kappa \rho \alpha \sigma l \varsigma$, descriptio), czyli retorycznego opisu, w tym przypadku budowli, choć dotyczyły one także osób, obrazów, rzeźb i różnych wydarzeńn ${ }^{32}$. Nauka pisania ekfrazodkąd uzyskały status osobnego gatunku, co stało się w okresie drugiej sofistyki ${ }^{33}$ - należała

\footnotetext{
30 Prokopiusz niewiele miejsca poświęca wyglądowi zewnętrznemu kościoła, niemal w całości koncentrując się na opisie tego, co kryje wnętrze. To podejście również świadczy o logice wykładu, a także o rozumieniu architektury bizantyńskiej, w której najważniejsze było wnętrze świątyni, olśniewające dekoracją i zupełnie przyćmiewające zewnętrzne mury, których ozdoba nierzadko sprowadzała się jedynie do prostego zróżnicowania kolorystycznego wątku muru (na przemian pasy z cegieł i białego kamienia). Jest to postawa zupełnie inna niż w przypadku antycznych świątyń pogańskich, przy wznoszeniu których wysiłek był skupiony na warstwie zewnętrznej. Wynikało to stąd, że środek ciężkości obrzędów religijnych znajdował się na zewnątrz - świątynia tworzyła więc odpowiednią oprawę dla sprawowanych ofiar. Zmiana nadeszła wraz z chrześcijaństwem, którego centrum jest misterium eucharystyczne, odbywające się w sanktuarium. Wierni są więc wpuszczeni do środka, by brać w nim udział - najważniejszy moment przeistoczenia pozostaje jednak niedostępny dla ich wzroku.

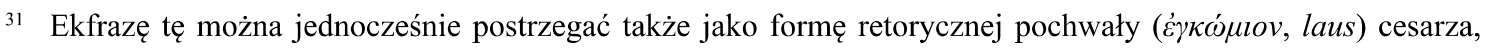
w której głównym powodem do chwały stało się wzniesienie wspaniałej świątyni.

32 V. S. Bartsch, J. Elsner, Eight Ways of Looking at an Ekphrasis, „Classical Philology”, 102/2007, nr 1, s. I-VI.

33 R. Popowski, Starożytny przewodnik po neapolitańskiej pinakotece, w: Filostrat Starszy, Obrazy, przeł., komentarzem i przypisami opatrz. R. Popowski, Warszawa 2004, „Biblioteka Antyczna”, s. 32.
} 
do wstępnych ćwiczeń retorycznych $(\pi \rho o \gamma v \mu \nu \alpha ́ \sigma \mu \alpha \tau \alpha \text {, praeexercitamenta })^{34}$. Nie inaczej było w Bizancjum ${ }^{35}$.

Nawet po pobieżnym przeanalizowaniu opisu Prokopiusza można stwierdzić, iż autor starał się spełnić retoryczne zalecenia związane z tworzeniem poprawnej ekfrazy, dla której probierzem było to, czy w wystarczająco plastyczny sposób odmalowuje przed oczami wyobraźni widza omawiany przedmiot, osobę lub zdarzenie. Założenie to było o tyle istotne, że przedmiot opisu zwykle nie był widziany przez słuchaczy. Należało więc sięgnąć po różnorodne środki retoryczne - wspomagane przez odpowiednią mimikę i gesty - aby uzyskać przekonywający efekt ${ }^{36}$. Przed takim zadaniem stanął też Prokopiusz z Cezarei, zapraszając swych odbiorców na swoistą periegezę po kościele Mądrości Bożej.

Omówiwszy pokrótce miejsce opisu w całym utworze, jego strukturę oraz treść, a także przynależność gatunkową, wypada przejść do szczegółowej analizy tekstu.

Prokopiusz najpierw przypomina dramatyczne okoliczności, w jakich doszło do podjęcia decyzji o budowie nowego kościoła Mądrości Bożej: Niegdyś pospólstwo i wszelkie szumowiny Bizancjum zbuntowaty się przeciw cesarzowi Justynianowi i wzniecili powstanie zwane „Nika” [...]. Ośmielili się spalić kościót chrześcijan (zwany przez Bizantyńczyków Madrościa - przydomkiem uznanym przez nich za najodpowiedniejszy dla Boga jako wezwanie jego przybytku ${ }^{37}$. [...] Tak oto cały kościót w tym czasie legt w gruzach i zamienit się w zgliszcza" (Aed. I.I.20-22) ${ }^{38}$. Informacje na ten temat przekazują także inni historycy, tak że zasadniczo nie są one powodem sporów badawczych. Ciekawe jest za to dalsze stwierdzenie: Niedtugo potem cesarz Justynian wznióst go $w$ tak doskonatym kolistym ksztatcie

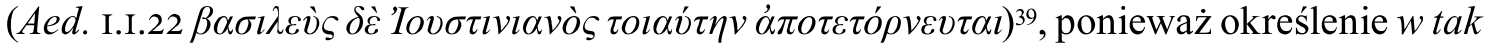
doskonatym kolistym ksztatcie znajdujemy u Platona w dialogu pt. Fajdros (Phaed. 234e), kiedy to Sokrates wypowiada się na temat odczytu Fajdrosa i prowokacyjnie zapytuje go

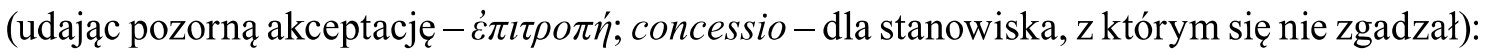
Jak to? To mamy i z tego względu odczyt chwalić, że autor powiedziat, co potrzeba, a nie tylko z tego punktu, że zwroty byty jasne, okragte, dosadne $i$ wycyzelowane? ${ }^{40}$ Prokopiusz w wyrażeniu tym bardziej chwali się swą erudycją, niż oddaje stan rzeczywisty budowli, która nie została wzniesiona na planie koła, choć jej plan cechuje się wyraźnym dążeniem do centralizacji, podkreślonym zwłaszcza przez środkową kopułę. Po oddaniu należnych honorów Antemiuszowi z Tralles oraz Izydorowi z Miletu, a także innym budowniczym (których

34 H. Cichocka, Ekfraza, w: Encyklopedia kultury bizantyńskiej, s. 157; eadem, Progymnasmata, w: op. cit., s. 411. V. także: W. Juszczak, Ekfraza poetycka w antycznej Grecji (wybrane przykłady), Warszawa 2012, zwł. s. 7-20.

35 H. Maguire, op. cit., s. 113. Zob. także: J. Elsner, op. cit., s. 39-40. Na temat dialogu Prokopiusza z antycznymi autorami, v. A. Kaldellis, Procopius of Caesarea. Tyranny, History, and Philosophy at the End of Antiquity, Philadelphia 2004, zwł. s. 24-45.

36 R. Popowski, op. cit., s. 34.

$37 \mathrm{Na}$ temat Prokopiuszowego wyjaśnienia wezwania kościoła Mądrości v. Av. Cameron, Procopius and the Church of St. Sophia, „The Harvard Theological Review”, 58/1965, nr 1, s. 161-163.

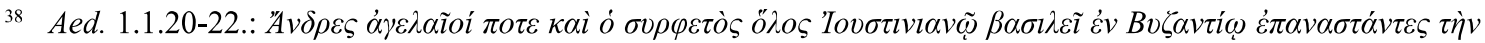

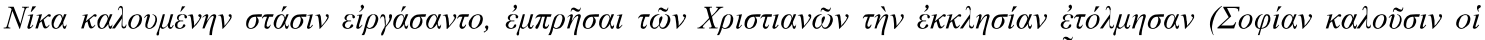

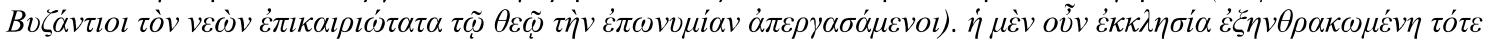
$\xi \dot{v} \mu \pi \alpha \sigma \alpha$ हैं $\varepsilon ı \tau o$.

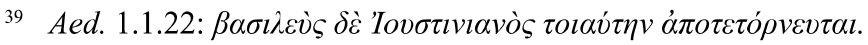

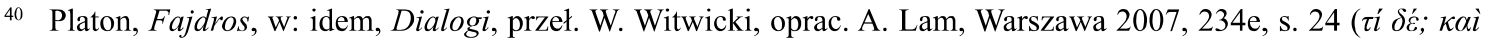

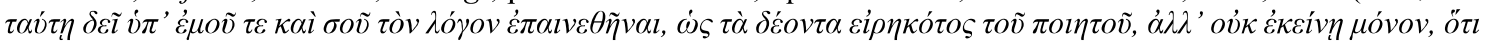

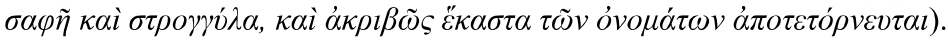


w Historii sekretnej ocenia zupełnie inaczej; Hist. arcan. 2I.7-25), wychwala piękno świątyni (Kościót ten stat się zatem widowiskiem niezwyklej piękności, olśniewajacym tych, którzy go ujrzeli, a zupetnie niewiarygodnym dla tych, którzy tylko o nim styszeli; Aed. I.I.274), co - choć mogło być też rzeczywistym przekonaniem autora - należy do standardowych formuł retorycznych, które miały za zadanie rozbudzić ciekawość odbiorcy i sprawić, żeby zechciał słuchać dalej. Następne zdania, mimo że nacechowane pewną przesadą ( $\dot{v} \pi \varepsilon \rho \beta o \lambda \dot{\eta}$, superlatio) i okraszone poetyckim porównaniem do okrętu (świątynia ulega też animizacji, gdyż ma spoglądać na resztę miasta), niewątpliwie odnosiły się także do rzeczywistej sytuacji, gdyż kościół Mądrości Bożej ze względu na swe nieprzeciętne rozmiary stanowił dominantę kompozycyjną w architektonicznym krajobrazie Konstantynopola: Sięgając nieba, wznosi się wysoko ponad inne budowle, niby okręt zakotwiczony pośród nich, i z wysokości spoglada $w$ dót na całe miasto. Jako że przynależy do niego, przysparza mu chwały swa kwitnaca pięknościa, ale też ksztattuje otoczenie właśnie dlatego, że stanowi jego część. Dominuje nad miastem, a jednocześnie wznosi się na taka wysokość, że można stamtąd podziwiać je całe niczym z wieży strażniczej (Aed. I.I.27) (2) $^{4}$ Prokopiusz wykazuje się w tym ustępie pewną urbanistyczną świadomością - budowla jest niezwykłą ozdobą miasta i mimo swej wyrazistości nie psuje spójności miejskiej tkanki, bo została weń dobrze wpisana, tak że wraz z innymi budynkami kształtuje przestrzeń Konstantynopola.

Kolejny akapit ma jednak charakter zdecydowanie retoryczny (Aed. I.I.28-29). Mimo wielu słów właściwie nie dostarcza konkretnych informacji, choć autor odnosi się w nim do wymiarów kościoła. Ogólnikowe sformułowania - jak na przykład dwukrotne podkreślanie idealnie harmonijnych proporcji - być może są wynikiem braku dokładnej wiedzy na temat wymiarów świątyni. $Z$ drugiej zaś strony autor nie był jeszcze pewny, czy już zdołał przekonać swych odbiorców o wspaniałości dzieła Justyniana. Możliwe, iż istotne są tu oba czynniki - czy Prokopiusz, znając dokładne wymiary budowli, nie zechciałby podzielić się tą wiedzą? Młodszy od niego o kilkadziesiąt lat Ewagriusz Scholastyk (ok. 532/537-ok. 594) w swej Historii Kościoła podaje precyzyjne dane na ten temat (Hist. eccl. 4.3I $)^{43}$. Więcej osobistej percepcji może się kryć w uwadze o świetle słonecznym (Aed. I.I.29-30), które, wpadając do wnętrza, odbija się od marmuru i napełnia kościół wspaniałą światłością, dając

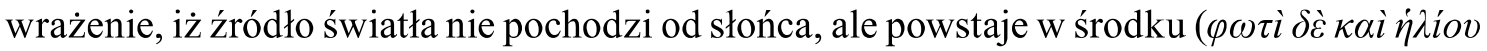

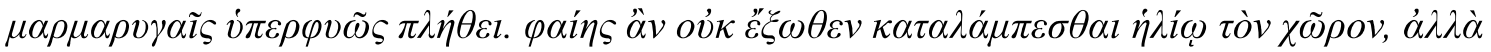

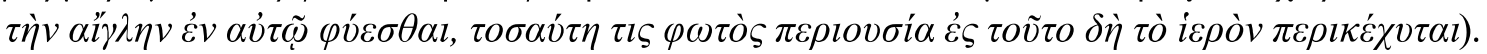
Jeśli więc jest to osobista uwaga, to świadczy ona o wrażliwości estetycznej Prokopiusza,

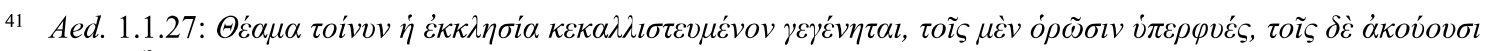
$\pi \alpha v \tau \varepsilon \lambda \tilde{\omega} \varsigma \ddot{\alpha} \pi \imath \sigma \tau o v$.

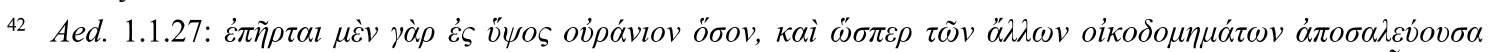

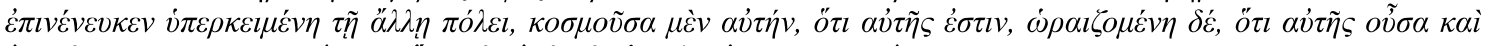

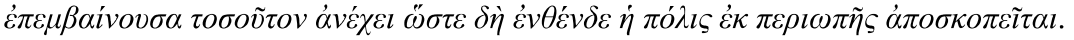

43 V. Ewagriusz Scholastyk, Historia Kościoła, przeł. S.J. Kazikowski, Warszawa 1990, 4.31, s. 204-205: Aby jednak jeszcze wyraźniej się zaznaczył zadziwiajacy rozmach całej budowli, muszę tu podać zarówno liczbę stóp jej dlugości, szerokości i wysokości, jak i rozwarcie oraz wysokość arkad. A więc dtugość od drzwi, usytuowanych naprzeciw świętej absydy, gdzie się składa zbawienna i bezkrwawa ofiarę, aż po samq absydę - wynosi 190 stóp: szerokość natomiast od pótnocnej strony do południowej mierzy stóp 115. Wysokość zaś mierzona od środka pótkuli sklepienia do posadzki liczy stóp 180 [...]; dtugość od wschodniej strony do zachodniej - stóp 260; rozległość wolnej między nimi przestrzeni - stóp 75.
} 
który nie pozostał obojętny na uroki gry światła ${ }^{44}$. Nie wydaje się to nieprawdopodobne, ponieważ kościół rzeczywiście wypełnia niesamowity blask, który w czasach Prokopiusza najpewniej był intensywniejszy choćby ze względu na świece, który oświetlały wnętrze ${ }^{45}$.

Po ogólnym wprowadzeniu autor przystępuje do szczegółowego opisu struktury budowli (Aed. I.I.3I-46). Informacje są na tyle dokładne, że należy założyć, iż dołożył on trudu, aby świątyni dokładnie się przyjrzeć, a następnie własnymi słowami opisać. Tak że ustęp ten nosi wyraźne ślady znajomości omawianego wnętrza $\mathrm{z}$ autopsji. Dają tu jednak o sobie znać pewne trudności w jasnym i ścisłym dookreśleniu opisywanych elementów architektonicznych. Mimo to da się też odnaleźć rzetelne informacje. Autor tłumaczy, iż kościół jest zamknięty od wschodu półkolistą absydą ( eksedry zwieńczone przez półkopuły, które podtrzymują centralną kopułę. Opis bywa też dość zawiły ze względu na zastosowane peryfrazy ( $\pi \varepsilon \rho i ́ \varphi \rho \alpha \sigma \iota \varsigma$, circumitio/circumlocutio), jak na przykład wtedy, gdy zamiast powiedzieć wprost, iż chodzi o konchę, mówi o „formie

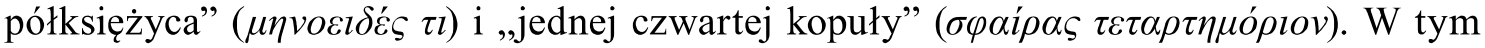
przypadku jednak mógł być to skutek dbałości o posługiwanie się klasyczną greką attycką.

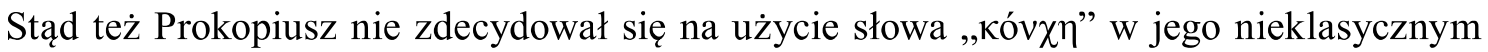
znaczeniu, czyli odnoszącym się do elementu architektonicznego ${ }^{46}$. Pozostając w części wschodniej, wspomina o kolumnach eksedr, które nie stoją wzdtuż linii prostej, lecz cofaja się na wzór półkola, jakby ustępowaty jedna przed drugą $w$ zbiorowym tańcu (Aed. I.I.35) ${ }^{47}$ i po raz kolejny używa poetyckiego porównania. Następnie przechodzi do części centralnej kościoła i sporo miejsca poświęca na omówienie czterech ogromnych podpór $(\lambda o ́ \varphi o l)$ w formie filarów $(\pi \varepsilon \sigma \sigma o i)$ - porównanych do stromych, górskich szczytów - dźwigających kopułę. Pomiędzy nimi - tak od strony południowej, jak i północnej-umieszczono po cztery

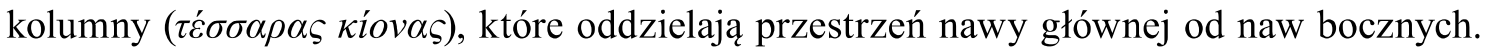
Zauważył również, iż do filarów przylegają też absydy ( $\dot{\alpha} \psi \tilde{\imath} \delta \varepsilon \varsigma)$, dwie od wschodu i dwie od zachodu (Aed. I.I.37-40). Omówiwszy filary, przechodzi do kopuły, ale tym razem nie

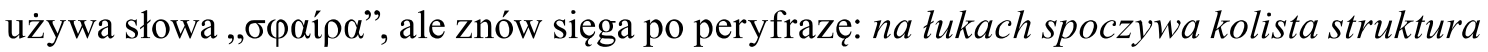
o ksztatcie cylindra (Aed. I.I.4I ${ }^{48}$. Dodaje nadto, że przez jej liczne otwory okienne wpada do wnętrza światło dzienne, a także - z charakterystyczną przesadą - iż góruje ona nad całym światem. Trafnie zauważa, że kopuła wsparta jest na czterech pendentywach ( $\tau \rho \dot{\gamma} \gamma \omega v \alpha)$, ale opis tej konstrukcji jest dość zawiły. Nie można jednak odmówić mu dokładności - autor dołożył starań, aby wypowiedzieć się możliwie precyzyjnie. Podkreśla również urodę kopuły - uznając ją za główną ozdobę świątyni: Na owym okręgu spoczywa wielka sferyczna kopuła, nadająca budowli nadzwyczaj piękny wyglad. Zdaje się nie być wsparta na solidnej konstrukcji muru, lecz nakrywać przestrzeń, jakby zwisała z nieba na złotym łańcuchu ${ }^{49}$

\footnotetext{
44 Cf. Paweł Silencjariusz, Iluminacja kopuły kościoła Mądrości Bożej, przeł. A. Szastyńska-Siemion, w: Muza chrześcijańska. Poezja grecka od II do XV wieku, wstęp, wybór, red. M. Starowieyski, Kraków 2014, s. 177-178.

45 Obecnie prowadzone są intensywne badania nad pierwotnym oddziaływaniem dzieł sztuki bizantyńskiej, w tym także wnętrz architektonicznych. Na ten temat w kontekście kościoła Mądrości Bożej w Konstantynopolu, v. N. Schibille, op. cit.; B. Pentcheva, Hagia Sophia and Multisensory Aesthetics, „Gesta”, 50/2/2011, s. 93-114.

46 V. P.Ł. Grotowski, op. cit., s. 56

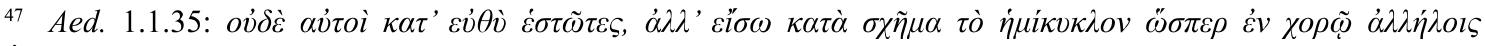

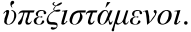

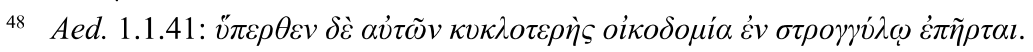

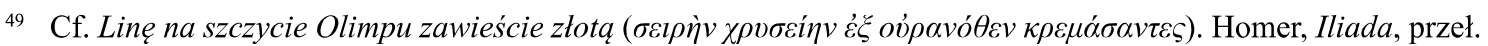
K. Jeżewska, oprac. J. Łanowski, Wrocław-Warszawa-Kraków-Gdańsk 1972, 8.18.
} 
(Aed. I.I.45-46) $)^{50}$. Uznawszy, iż kopuła została należycie opisana, w rozbudowany sposób podsumowuje niezwykłość i piękno tej partii kościoła Mądrości Bożej: kolejny raz wspomina o harmonii wszystkich elementów, a także - być może odwołując się do własnego odczucia - dodaje, że gdy patrzy się na kopułę, to wszystko wiruje przed oczami, tak że nie wiadomo, w którą stronę skierować wzrok (Aed. I.I.47-49).

Przed przejściem do omówienia pozostałych części kościoła, Prokopiusz pozwala sobie na dłuższą uwagę na temat sposobu wzniesienia filarów (Aed. I.I.50-54). Choć na wstępie skromnie podkreśla, iż jego umysł nie jest zdolny, aby pojąć wszystkie zawiłości trudnej sztuki architektonicznej - co jest standardowym chwytem retorycznym - to po chwili daje popis swej erudycji, dokładnie tłumacząc metodę budowlaną, dzięki której filary są na tyle mocne, że mogą udźwignąć ciężar kopuły i zapewnić całej konstrukcji odpowiednią stabilność. Mimo precyzji i stosowania fachowej terminologii można wychwycić również pewne nieścisłości (np. to, że mówi o prostokątnym planie filarów, podczas gdy jest on w rzeczywistości nieregularny), które ukazują, iż Prokopiusz nie posiadał wystarczająco dokładnej wiedzy z zakresu architektury. Dlatego też opis ten - mimo że na pierwszy rzut oka niezwykle precyzyjny - stanowi przedmiot dyskusji, ponieważ niektórzy badacze uważają go za mało wiarygodny ${ }^{\mathrm{sI}}$.

Autor reszcie kościoła poświęca mniej uwagi. Odnotowuje jednak najistotniejsze partie (Aed. I.I.54-59), czyli kolumnady ( $\sigma \tau o \alpha i ́)$ oddzielające nawę główną od bocznych (w których

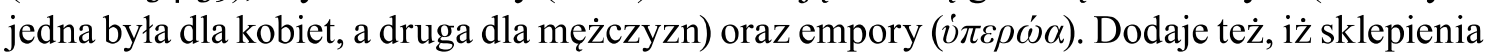
pokryte są złotem, którego blask przyćmiewa jednak światło odbite od marmuru. Ustęp ten tylko na początku przekazuje stosunkowo dokładne informacje na temat formy architektonicznej, gdyż szybko przechodzi w passus niezwykle zretoryzowany, zaczynający się od kilku pytań retorycznych, w których autor sugeruje, iż piękno świątyni jest tak niebywałe, iż nikt nie zdoła oddać go słowami. Feerię barw związaną z różnokolorowymi marmurami oraz złotem w poetycki sposób przyrównuje do łąki pełnej kwitnących kwiatów ${ }^{52}$ : Oto można by wyobrazić sobie, że stapamy po łace petnej rozkwitających kwiatów. Kogóż bowiem nie zadziwitby purpurowy odcień jednych marmurów, a zielona barwa innych, te, na których zakwita szkarłat, i te, które jaśnieja biela, wreszcie te, na których Natura niczym malarz wymieszała różne, nawet najbardziej skontrastowane barwy (Aed. I.I.60)53. Mimo wyraźnej retorycznej przesady powyższego cytatu nie można z góry założyć, iż Prokopiusz faktycznie nie był zachwycony kolorystyką wnętrza, tym bardziej że już wcześniej dawał znać, iż nie jest obojętny na wartości estetyczne ${ }^{54}$. Być może jednak nie chciał odejść od pewnych schematów i osobiste doznania ubrał w dość konwencjonalne słowa, zrozumiałe dla kręgu późnoantycznych odbiorców. Autor uważa również, iż tak wspaniała forma architektoniczna oraz dekoracja pomagają wiernym wznosić swe myśli do Boga, który w takim wnętrzu musi

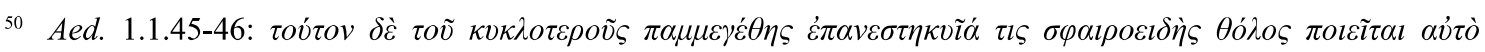

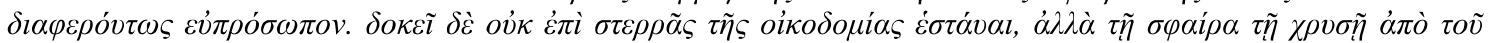

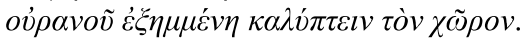

51 V. Prokopiusz z Cezarei, O budowlach, s. 88, przyp. 32.

52 V. N. Schibille, op. cit., s. 99-109.

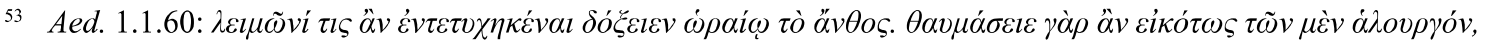

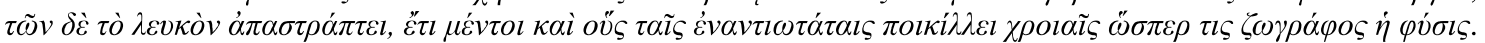

54 V. A. Cutler, Structure and Aesthetic at Hagia Sophia in Constantinople, ,The Journal of Aesthetics and Art Criticism", 25/1966, nr 1, s. 27-35.
} 
być blisko. Podkreśla też, iż olśniewające wrażenie świątynia robi zawsze, a nie tylko podczas pierwszej wizyty. Jej piękno raduje modlących się, a nawet czyni ich lepszymi, gdyż po wyjściu oddają się wzniosłym rozmowom na temat budowli (Aed. I.I.6I-63). Z pewnością i ten ustęp tekstu pełen jest przesady, ale za jej sprawą dobitnie uwypukla niezwykłość świątyni Mądrości Bożej - trudno, by ktoś po takim opisie pozostał niewzruszony i nie zapałał chęcią obejrzenia jej na własne oczy. Ponadto Prokopiusz w ten sposób ukazał swój pisarski kunszt, gdyż posługiwanie się rozmaitymi zabiegami retorycznymi miało dawać odbiorcom przyjemność, a wydaje się, iż w opisie tego kościoła zdołał osiągnąć to w bardzo udany sposób. Nie można bowiem zapominać, iż bizantyński historyk nie pisał, aby dziś można było - cal po calu - odtworzyć dzieło Justyniana, ale by wychwalić fundatora ${ }^{55}$ i dać opis, który przemówi do wyobraźni odbiorców (choć cel informacyjny z pewnością nie jest bez znaczenia). Na tym passusie właściwie kończy się opis świątyni. Prokopiusz wspomina jeszcze - również wyolbrzymiając - o darach Justyniana (Aed. I.I.64-66), na koniec zaś podaje jeszcze jedną anegdotę, która podkreśla zaangażowanie i mądrość cesarza (Aed. I.I.67-78). Mimo że zaprezentowanie Justyniana jako opatrznościowego męża można uznać za całkowitą inwencję twórczą pisarza, to z pewnością kolejne wspomnienie o trudnościach technicznych podkreśla, jak niesamowitego i innowacyjnego dzieła udało się dokonać architektom.

\section{Wnioski}

Przeprowadzona analiza ukazuje, iż Prokopiusz z Cezarei pozostawił nam wartościowy opis kościoła Mądrości Bożej w Konstantynopolu. Nie bez znaczenia jest jednak fakt, iż świątynia nadal istnieje, co ułatwia zrozumienie niektórych fragmentów - bez tego jawiłyby się one jako dość niejasne. Mimo że przy bliższym oglądzie daje o sobie znać brak u autora szczegółowej wiedzy dotyczącej architektury, to należy przyznać, iż zasadniczo zdołał on poprawnic opisać konstrukcję budowli. Widać także dbałość o precyzję i dokładność - choć nie zawsze uwieńczoną sukcesem.

Opisowi nie brak też chwytów retorycznych - szczególnie częste są hiperbole, rozbudowane i poetyckie porównania, a także peryfrazy i pytania retoryczne - oraz konwencjonalnych zwrotów i aluzji do literatury klasycznej. Trudno oprzeć się wrażeniu, iż autor bardzo starał się, aby jego styl dawał odbiorcom przyjemność. Stąd też partie dotyczące kwestii technicznych zwykle przeplatają się z ustępami o charakterze retorycznym, które zarówno zdobią tekst, jak i czynią go przystępniejszym.

Można zatem uznać, iż Prokopiusz w swym opisie uczynił zadość tak wymogom rzetelnej historiografii, jak i zaleceniom retorycznym dotyczącym ekfrazy. Tak też poucza (docere) i zachwyca (delectare), ale i porusza (movere) dzięki anegdotom, które spajają cały tekst. Oczywiście można poczynić sporo zastrzeżeń - zwłaszcza jeśli idzie o precyzję opisu architektury - ale nie należy przy tym zapominać, iż celem było przede wszystkim wychwalenie Justyniana jako niestrudzonego budowniczego. Także współczesne oczekiwania, zwłaszcza badaczy architektury, są odmienne i znacznie bardziej rygorystyczne, Prokopiusz jednak nie obiecywał fachowego traktatu, ale tekst, który nie pozwoli zapomnieć o dokonaniach cesarza Justyniana I. I cel ten w pełni osiągnął.

55 V. J. Elsner, op. cit., s. 43-49. 


\section{"Procopius of Caesarea's description of the church of Hagia Sophia in Constantinople - between historiography and rhetoric" Summary}

The sixth-century historian Procopius of Caesarea described the church of Hagia Sophia

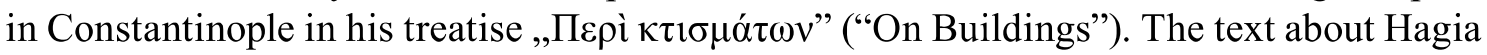
Sophia is the only surviving historical source for the original Justinianic edifice before the collapse of its first dome in 558. This detailed and elaborate description of the church is an example of ekphrasis. Ekphrasis is a rhetorical technique which makes the described object visible. In this paper I will attempt to analyse how far Procopius' description is a rhetorical exercise, and how far it is a trustworthy historical source.

Keywords: Procopius of Caesarea, ekphrasis, Hagia Sophia, "On Buildings"

Nota o Autorze: Magdalena Garnczarska odbywa obecnie studia doktoranckie na Wydziale Historycznym Uniwersytetu Jagiellońskiego w Krakowie oraz studia z filologii klasycznej. Do jej głównych zainteresowań badawczych należą sztuka bizantyńska, zwłaszcza jej ikonografia, a także bizantyńskie teksty dotyczące zagadnień artystycznych. 